\title{
Operating Under Erasure: Race/Language/Identity
}

\author{
Awad Ibrahim (University of Ottawa)
}

\begin{abstract}
:
Based on a critical ethnographic research project, this paper is about the impact of becoming Black on ESL learning; that is, the interrelation between identity formation, identification, race, culture and second language learning. It contends that a group of French-speaking immigrant and refugee continental francophone African youths who are attending an urban Franco-Ontarian high school in southwestern Ontario, Canada, enters, so to speak, a social imaginary, a discursive space in which they are already imagined, constructed, and thus treated as Blacks by hegemonic discourses and groups. This imaginary is directly implicated in whom they identify with (Black America), which in turn influences what and how they linguistically and culturally learn. They learn Black English as a second language (BESL), which they access in hip-hop culture and rap lyrical and linguistic styles. Conducted within an interdisciplinary framework, this critical ethnography shows that (ESL) learning is neither neutral nor without its politics and pedagogy of desire and investment.
\end{abstract}

\begin{abstract}
Résumé:
En se basant sur un projet de recherche ethnographique critique, l'auteur considère l'effet de devenir Noir dans l'étude d'anglais comme langue seconde (ESL), c'est-à-dire la corrélation entre la formation de l'identité, l'identification, la race, la culture, et l'étude de la seconde langue. Il s'agit d'un groupe de jeunes immigrants et réfugiés francophones venant d'Afrique et allant à une école secondaire de langue française dans un centre urbain du sud-ouest de l'Ontario, Canada. L'auteur soutient que ces jeunes, pour le dire, entrent dans un espace social, décousu, imaginaire dans lequel ils se sont déjà imaginés, composés, et donc traités comme des Noirs à cause d'un discours hégémoniques. Cet espace imaginaire est directement impliqué sur ceux avec lesquels ils s'identifient notament des Afro-américains et qui, à leur tour, influencent sur ce qu'ils apprennent en langue et en culture. Ils ont appris l'anglais des Noirs comme langue seconde (BESL) qu'ils ont appris par la culture hip-hop, les paroles et l'expression linguistique du Rap. Conduit dans un cadre interdisciplinaire, cette étude ethnographique critique souligne le fait que l'apprentissage de langue (ESL) n'est ni neutre, ni indépendant des politiques et de la pédagogie du désir et de l'investissement.
\end{abstract}

The idea of race, racialization, and racism are inescapable topics that arise in the contact zones created by teaching English worldwide... Ryuko Rubota \& Angel Lin (2006) 


\section{Operating Under Erasure: Race/Language/Identity}

This paper is about race - or better racialization - and how it is connected to identity and second language acquisition (SLA). Consistently, I argue, race is left unsaid in the field of SLA. Reviewing the literature and exploring an ethnographic study I conducted in an urban Franco-Ontarian high school in southwestern Ontario, Canada, I demonstrate that race is salient, if not absolutely pivotal, in the process of second language learning. In this study, a group of French-speaking, immigrant and refugee, continental African youths enters a social imaginary where they are already constructed as Blacks. ${ }^{1}$ This imaginary, I will show, directly impacts their social identity formation processes, whom they identify with, and what they learn. They learn Black English as a Second Language (BESL), which they access in and through hip-hop culture and the language of rap. We need, I conclude, to link the macro with the micro (i.e. the cultural, the political and the linguistic), on the one hand, and social identities, race in particular, with the technologies of second language teaching and learning, on the other. Ultimately, the aim is to link the word and the world and to situate our pedagogy and ourselves as second language teachers within a cultural-and-geopolitical world.

Identity is not as transparent or unproblematic as we think. Perhaps instead of thinking of identity as already accomplished fact '... we should think, instead, of identity as a 'production,' which is never complete, always in process, and always constituted within, not outside, representation' (Hall, 1990, p. 222).

Recruited under the umbrella of 'crisis,' identities are coming back; they are 'returning' Hall (1990). By 'returning,' Hall is not implying that the question of identity ever went away - after all, invisibility only means misrecognition, not inexistence - but that it is returning with 'a particular kind of force.' This forceful return, in my view, is linked to poststructural, postcolonial, postmodern, antiracist and feminist discourses which place identity formation and performance in that complex intersection of multiple discourses, including discourses of difference, subjectivity, language, history, memory, and power relations (cf. Althusser, 1971; du Gay, Evans \& Redman, 2000; Kubota \& Lin, 2006; Norton, 1997; Pennycook, 2000; Rajchman; 1995; Woodward, 1997; Yon, 2000).

This 'return of identities' into the field of SLA, and bilingual processes in general, is exceptionally forceful. In fact, a plethora of work on the intersection of multiple axes of identity is now emerging in Applied Linguistics (cf. Amin, 1997; 2006; Cummins, 2000; Goldstein, 1997; Gumperz, 1982; Heller with Campbell, Dalley \& Patrick, 1999; Ibrahim, 1999, 2000a, 2000b, 2000c, 2001, 2003; Kubota and Lin, 2006; Morgan, 1997, 1998; Nelson, 1999; Norton, 1997, 2000; Norton and Toohey, 2004; Pennycook, 1999, 2000; 2004; Rampton, 1995; 2006; Toohey, 2000; Wong, 2000; among many others). This literature calls attention to two significant phenomena: the dialectic or dialogic relationship 
between the macro and the micro on the one hand - that is, the relationship between the minute everyday reality of classroom teaching and the larger social spheres - and the connection between identity, and second language theories and technologies of teaching and learning on the other. Within these axes of identity, however, race has received little attention, if any. My intention in this paper, therefore, is to fill in some of that gap by looking at both phenomena. That is, I intend to ethnographically explore the dialogue between the macro (i.e. social) and the micro (i.e. everyday in-class practice and pedagogy) and to see, in turn, the extent to which this dialogue influences not only identity formation processes, but language learning as well.

The paper is guided by the following questions. If identities are ongoing 'productions,' unstable points of identification or suture (Silverman, 2000) ${ }^{2}$ that are given birth to at the borderland between the Self and the Other (Bakhtin, 1990, p. 365; Woodward, 1997, p. 39); and if this dialectic relationship between the Self and the Other is based on unequal historical relations of power, then: (a) what is the impact of this relationship on how the Self 'forms' and 'performs' itself, and (b) how are these identity formation processes implicated in how and what one learns? Put otherwise, do societal macro structures play any role in our micro identity formation processes, and are these processes, in turn, connected to SLA? If so, how? In the case of race, which is made absent in SLA literature, how does one conceptualize its relationship to identity formation processes and second language learning in general?

This paper is based on a 'critical ethnographic research project'. It will trace the impact of becoming Black on ESL learning (i.e. the relationship between technologies of identity formation and second language learning). It contends that a group of French-speaking, immigrant and refugee, continental francophone African youths attending an urban Franco-Ontarian high school in southwestern Ontario, Canada, enters, so to speak, a 'social imaginary' or a discursive space in which they are already imagined, constructed, and thus treated as 'Blacks' by hegemonic discourses and groups. This imaginary is directly implicated with whom they identify (Black America), which in turn influences what and how they linguistically and culturally learn. They learn Black English as a Second Language (BESL), which they access in hip-hop culture, and rap lyrical and linguistic styles. This critical ethnography shows, I conclude, that (ESL) learning is neither neutral nor without its politics and pedagogy of desire and investment.

In what follows, I shall first review the literature that looks at the intersection of race, identity, and second language learning, given its centrality to my research. Secondly, I shall pay special attention to 'the politics of identity.' I then discuss my ethnographic study, and offer a conclusion on the need to link the macro and the micro, identity and learning, classroom pedagogy, and the political and the cultural. 


\section{The Alchemy of Race, Identity and Second Language Learning}

The ethnolinguistic terms in which the children of Dominican immigrants in the US think of themselves (i.e. as 'Spanish' or 'Hispanic') are frequently at odds with the phenotype-based racial terms 'Black' or 'African American,' applied to them by others in the United States. The Spanish language is central to resisting such phenotype-racial categorizations, which deny Dominican Americans their Hispanic ethnicity.' After a punctilious and painstaking review of the literature, this statement by Bailey (2000, p. 555, my emphasis) is as close as I got to what I want to explore in this article: linking race, language and identity. Bailey's (2000) main interest, which I shall explore later, is interconnected to: (a) how Black immigrants translate and negotiate ${ }^{3}$ the North American Black/White dichotomy, and (b) how the Spanish language is invoked as an identity location, a way of saying: 'Contrary to what you see, this is where I want to be located (as Hispanic).' Significantly, both phenomena are performed against the backdrop of racial politics in North America.

In North America, bodies are 'marked' by history where Blackness is read not so much in terms of ethnicity, but through an essentialized gaze where skin colour, hair, nose shape, and so on determine who one 'is' (West, 2000; Omi and Winant, 1998; hooks, 1992; Ibrahim, 2000a, 2000b, 2008). However, we have long known that scientifically (i.e. biologically) speaking, race does not exist ${ }^{4}$ (Back and Solomos, 2000; Gilroy, 2000). And if meaning does not lie in the object (Hall, 1997), phenotypes for example, then what exactly are we talking about when we discuss 'race'?

In the social sciences, especially after the mid-twentieth century, biologistic notions of race were rejected. Instead, we have race as a social, historical, and political category (Cox, 2000; Essed \& Goldberg, 2002; San Juan, Jr., 2002). The biological death of race should thus be equated with its social, historical and political birth since, without a racial identity in North America, 'one is in danger of having no identity at all' (Omi \& Winant, 1998, p. 16). This is because, '[w]e utilize race to provide clues about who a person is. This fact is made painfully clear when we encounter someone whom we cannot conveniently racially categorize ... Such an encounter,' Omi and Winant (1998, p.16) explain, 'becomes a source of discomfort and momentarily a crisis of racial meaning.' Statements such as, 'Funny, you don't look black,' for Omi and Winant, 'betray an underlying image of what black should be' (1998, p.16). What one 'looks like,' here, is equated with what one 'is like.' As a result, race becomes a process of signification, an ideological event where the meaning does not lie in the object (skin colour for example) but in how the object is signified. The emphasis should therefore not be on 'race', but on the process of its signification or racialization, which is a product of what Lopez and Espiritu (1990) call 'racial lumping.' This, in turn, produces a 'pan-ethnic' formula. Here race and ethnicity (defined in terms 
of language, culture and religion) are fused together, and internal differences among and within so-called racial groups are erased because, from an outsider's point of view, 'They all look alike!' This same process of racial lumping or racialization, importantly, is closely connected to racism and a particular racial logic: the establishment and maintenance of a 'color line' (Omi \& Winant, 1998).

For these authors, racial logic is historical and began with slavery in North America. By the end of the seventeenth century, 'Blackness' was consolidated as the umbrella term under which Africans - whose specific identities were Ibo, Yoruba, Fulani, etc. - were rendered 'one' racial(ized) group. This reflected a move from ethnicity to race where the latter obscured or rendered the former secondary. Following Omi and Winant, I use the term 'racialization' to signify the extension of racial meaning to a previously racially unclassified relationship, social practice or group. Racialization is an ideological process, a historically specific one. Racial ideology is constructed from pre-existing conceptual (or, if one prefers, 'discursive') elements and emerges from the struggles of competing political projects and ideas seeking to articulate similar elements differently' (1998, p.18). Therefore, it is significant, I conclude, to put the emphasis not on the definition of 'race', but on the process of racialization and on one of its painful side effects: racism.

This alchemic ${ }^{5}$ formula of racialization is directly implicated in identity formation processes which in turn mediate what one learns and how. As noted above, identity is not a thetic or a static category; it is a dialogic process; a split between Self and Other. It is in this dialogue with the Other that the Self knows its virtues; it is in that split that the Other enters the Self. Such dialogue, I will show in my research, especially between Blackness and Whiteness, governs not only how the former sees itself, but also how others see it (Foucault, 1984). The Self, the Identity, the Subject is no longer found in isolation nor is it saturated by the other. On the contrary, it is a meeting point between multiple discourses, including discourses of race and Otherness.

Hall (2000) refers to the process of identity formation as the 'New identity', which he distinguishes from the 'Old identity.' Old and New identities are interchangeably used with Old and New ethnicities. The discourse and the logic of the Old identity, Hall (2000, p.145) explains, ' . . contains the notion of the true self, some real self inside there, hiding inside the husks of the false selves that we present to the rest of world. It is a kind of guarantee of authenticity. Not until we get really inside ... do we know what we are 'really saying'. It is, in short, an expression of a Cartesian, stable self where the subject is situated within static discourses of history, self, and memory.

The New identity discourse, on the other hand, is more complexly different. It does not neglect history or the multiple discourses within which the subject finds herself. Neither does this discourse neglect the contradictory nature 
of these discourses, power relations (the politics of positioning), or the dialogic relationship between the Self and the Other. For Bakhtin (1990, p.365), this dialogic relationship is indeed 'a dialogue of social forces perceived not only in their static co-existence, but ... a as a dialogue of different times, epochs and days.' It is 'a dialogue that is forever dying, living, being born: co-existence and becoming are here fused into an indissoluble concrete unity that is contradictory, multi-speeched and heterogeneous' (Bakhtin, 1990, p.365).

The field of SLA, according to Hall and Eggington (2000), is still dominated by the discourse of Old identity, cognitive psychology and psycholinguistics. When it comes to public discussion of teaching English as an additional language, Hall \& Eggington (2000) find that discussion 'typically focuses on such aspects of pedagogy as the latest teaching methods and techniques, multimedia materials and resources available for student use, and the 'how to's' of managing student behavior' (p. 1). Obviously, the discourse of Old identity does not allow for a dialectic relation between micro - 'how to's' - and macro links between classroom teaching and students seen in terms of social class, age, race, gender, and their location in broader social, cultural, and political contexts (Pennycook, 2000, p.90).

In spite of this, the discursive influence of the New identity in the field of SLA is steadily increasing. Briefly, I want to review the literature that makes use of the intersection of race, identity and second language teaching and learning, limited though it may be. Here, 'ethnicity' is mainly used as an operative or theoretical tool in the literature, largely at the expense of 'race,' or the couplet: race/ethnicity.

\section{Mapping the Field}

Approaching SLA chiefly from a theoretical, sociohistorical and political vantage point, Pennycook $(1998,1999,2000)$ is exceptionally insightful in exploring the connection between political and cultural aspects of English language teaching (ELT) and, to a lesser extent, learning. Pennycook points to the need for 'critical applied linguistics' that does not take lightly the idea or discourse of teaching English as an international language. The English language and its teaching (and learning), Pennycook contends, has a long, dark history of Empire and colonialism. He sees a strong connection between the discourses of Old identity, colonialism and ELT. As he puts it,

ELT theories and practices that emanate from the former colonial powers still carry the traces of those colonial histories both because of the long history of direct connections between ELT and colonialism and because such theories and practices derive from broader European cultures and ideologies that themselves are products of colonialism (Pennycook, 1998, p.19). 
There is a need, Pennycook (1998) continues, to see the classroom not as a 'closed box' where teachers try to help their students learn a language, which 'is a set of structures, pronunciation, or acts that students need to learn' (p. 19). Instead, Pennycook (1998) argues, we need to see the classroom as a site of possibility and struggle; as a complex social and cultural space where the macro is interwoven with the micro (see also Kubota \& Lin, 2006).

In Talburt and Stewart's (1999) ethnographic study of students' in- and out-of-class cultural learning during a 5-week, study abroad program in Spain, they concurred with Pennycook. That is, the authors found a strong correlation between formal and informal learning experiences, and the students' gender and race. The only African American student in this program, Misheila, experienced the most restrictive access to, and interactions with, members of the host culture (Spain); indeed, she encountered insidious racism that hindered not only her second language learning, but also her relations with her classmates. As teachers, Talburt and Stewart were not prepared for such a situation, nor was it anywhere in the literature they reviewed; hence, they called for a sustained discussion of students' sociocultural differences as part of the formal curriculum.

Eckert and McConnell-Ginet (1999) explore ethnographically the complex ways in which linguistic practices are used to demarcate territories, invoke identities and eventually create a 'community of practice,' which they define as 'a group whose joint engagement in some activity or enterprise is sufficiently intensive to give rise over time to a repertoire of shared practices' (p. 185). Their study is about 'a crowd of Asian-American kids' in an ethnically heterogeneous junior high school in northern California (p.185). This crowd 'hangs out in a spot that is generally known in the school as the "Asian Wall", (Eckert \& Connell-Ginet, 1999: 185). This is a wall that is observed and noted more by outsiders and onlookers than by insiders-Asian students-and its presence is linked to the latter's limited language proficiency. The authors point to the internal diversity of 'Asian Americanness,' a category both embraced and resisted by the 'kids.' Those who embrace or enter the 'Asian Wall,' the authors explain, do so not 'so much out of a sense of a pre-existing commonality [remember the 'pan-ethnic' formula here], as out of a shared need to construct a commonality around which they can join forces' (p. 186). One conclusion of interest to my study is the strong dependence and co-construction of gender, race/ethnicity, heterosexuality, life stage, and social status. In other words, none of these categories is or can be dealt with separately. In this study, language is both a medium of expression and of construction.

In an interesting way, Eckert and McConnell-Ginet's study is similar to Rampton's (1995) detailed ethnographic study of how linguistic practice is used both to abuse and create solidarity. This is done through 'ritual expressions' that bank on certain second language expressions, and do not require full mastery of 
the language. Therefore in Rampton's study as in Eckert and McConnell-Ginet's study language is also used as a social demarcation. Heller with Campbell, Dalley \& Patrick (1999) find a similar phenomenon in their study of young FrancoOntarians; in their study, English is used contextually to mark oneself differently. The Franco-Ontarian students use English to sustain friendships and to mark themselves as bilingual or multilingual. They do so, precisely, because they are asked not to, where speaking French or complying becomes 'not cool.'

Using influential theorists like Cummins and Bourdieu, Norton (1997, 2000) introduces a poststructural theory of subjectivity to the fields of SLA and Teaching English as a Second Language (TESL). She argues that the question 'Who am I?' cannot be understood apart from the question 'What can I do?' She defines subjectivity or identity as 'how people understand their relationship to the world, how that relationship is constructed across time and space, and how people understand their possibilities for the future' (Norton, 1997, p. 410). Like Pennycook, Norton argues that a successful learner is one who is able to summon up, or construct, a social identity that enables him/her to invest, struggle over, and hence create a symbolic capital, a linguistic repertoire. Learning here is linked to what one does with the language and how much access one has to it. Using Norton's theory, Amin (1997) has found a strong correlation between accent, race and ELT. Working mostly with teachers of colour, Amin showed that people of colour who may have English as their first language, but who have a nonAmerican/Canadian accent (such as people from Caribbean, African, or Asian countries) are not considered native speakers. Hence, she found that in the minds of the students in her study native English status is linked to Whiteness.

Bailey's (2000) study, however, deserves special attention given its similarity to mine. Bailey looks at how young Dominicans negotiate identity, language and the politics of racialization in the United States. The study, which takes place on Rhode Island, shows ongoing tensions between how Black immigrants define themselves compared to how they are defined. As Bailey (2000) puts it, 'Dominican American self-definition of race in terms of ethnolinguistic heritage - as 'Spanish,' 'Dominican,' or 'Hispanic' - runs counter to popular and historical US notions of race in which the African-descent phenotype has preceded all other criteria (e.g. national origin, language, or religion) for social classification' (p. 555). This is because 'African-descent RACE has historically been treated as equivalent to African-descent ETHNICITY in the US . . . with the result that immigrants of African descent have largely merged into the African American population by the second generation' (p. 555). Of interest in Bailey's study is the success that Wilson, a 17-year-old, first generation immigrant has in using language to invoke, express, and negotiate his multiple ethnic/racial identities. He is able, for example, to skilfully use multiple language varieties to situationally highlight Dominican, American, and African- 
American facets of his Dominican-American identity. Bailey (2000) thus concludes, 'Language is a medium which affords individual social actors the freedom to highlight various aspects of identity; but it is also a medium through which constraining, hegemonic forms of ascription - e.g. social classification based on phenotype - are invoked and reconstituted' (p. 557).

My intent for this review of the literature is to provide an argument that a connection between race, identity, and SLA can be established. My study is both building on and complicating this literature and expanding it in different directions. My aim in what follows is to introduce my study where I hope to show the relationship between becoming Black and SLA.

\section{An Ethnography of Performance: Methods, Participants, and Definitions}

The present study constitutes part of a larger critical ethnographic research project ${ }^{6}$ I conducted at Marie-Victorin School ${ }^{7}$ between January and June 1996 (Ibrahim, 1998). I also revisited the school in 2003. The study made use of the ethnography of performance (Ibrahim, 2001). This is an ethnographic approach/method that builds on Butler's (1999) notion of performativity. For Butler, performativity is a concept that framed in terms of repetition, parody and a continual act of becoming any sense of fixity. It suggests that the subject can never be fully and completely; rather, it is always in progress, always becoming. Gender and race are not static categories, either, but are repeated stylizations of the body; a set of recurrent acts, words, gestures, or what Barthes (1983) calls complex semiological languages. These are signs that are open for signification and different readings since they cannot produce verbal utterances, yet are ready to be spoken. These complex languages, Butler explains, are produced and performed on the surface of our bodies: in and through our modes of dress, walk, hairstyles, lip-gloss, and so on. Hence, we perform our identities, desires, and investments, at least in part, in and through our complex semiological languages of dress, walk, and talk.

Methodologically, this theory of subjectivity has direct implications for ethnographic research. Ethnography of performance argues that, if identities are performed in and through complex semiological languages of our dress, walk, and talk, then they become our best access as researchers to our research subjects' inner-identities (i.e. what they think and desire, and how they long to represent themselves and to be represented). In other words, research subjects' innerselves/identities are best accessed in and through observing what people do and perform on the surface of their bodies. To have a complete picture of our research subjects' identities, if this is ever possible, we need to observe them in different places, at different times, and over extended periods of time; and ask them to verbalize and reflect upon their own performances/actions. That is what I did. 
First, it is worth noting that, at the time I was conducting my research, I was well acquainted with the school, Marie Victorin (MV), and its population especially its African population - since I had been working on another research project in the same school for almost two years. I started my research by 'hanging out $^{8}$ with African students at least once a week, and in most cases, two or three times from January to June of 1996. I was a participant-observer, keeping regular notes and weekly diaries. I then conducted a phase of extensive observation involving sixteen students - ten boys and six girls - between the ages of fourteen and twenty. The girls were Somali-speakers form Somalia and Djibouti. Of the ten boys, six were Somali-speakers - from Somalia and Djibouti, two were Senegalese, one was Ethiopian, and one was Togolese. Without exception, all of the African students in MV were at least trilingual, speaking English, French, and their mother tongues, with various postcolonial histories of language learning and degrees of fluency in each language. Their length of stay in Canada varied, as did their legal status (e.g. some were immigrants, but the majority were refugees). I observed them in and out of their classrooms as well as in and out of school. With the consent of the students and their parents, I interviewed them, individually or in groups, either in English or in French, though primarily in French. Interview sessions went from one and a half to four hours. I also videotaped them and, on two occasions, handed over the tape recorder to the students to capture their 'natural' interactions among themselves when I was not present. I attended soirées, plays, basketball games, and graduations, and was delighted to be invited to their homes. I transcribed and translated the interviews and some of the videotapes, and analyzed the data by grouping the interviews by theme, category and subject.

The research site was a small, urban, Franco-Ontarian intermediate and high school (grades 7 to 12), located in southwestern Ontario. Approximately 400 students from various ethnic, racial, cultural, religious, and linguistic backgrounds were enrolled in MV. Though it is a French-language school, the language most commonly spoken by students in the school corridors and hallways was English. Arabic, Somali, and Farsi were also spoken at times. Besides their gendered and racialized experiences, their youth and refugee status were vital to their moments of identification (i.e. where and how they saw themselves reflected in the mirror of their society). Put differently, I contend that, once in North America, these youths were faced with a social imaginary in which they were already imagined as Blacks. This social imaginary was directly implicated in how and with whom they identified, which, in turn, influenced what they learned, linguistically and culturally. What they did learn is Black Stylized English (BSE), as we shall see, which they accessed in and through Black popular culture. They learned this by taking up, and taking ownership over, the rap linguistic and musical genre and, in different ways, acquiring and rearticulating a hip-hop cultural identity. 
To explain, BSE is a subcategory of Black English (BE). BE is what Smitherman (2000) refers to as Black talk which has its own grammar, morphology and syntax. BSE, on the other hand, refers to ways of speaking that do not depend on full mastery of the language. It banks more on ritual expressions such as whassup, whadap, whassup [what is happening] my Nigger, and yo, yo homeboy [cool friend], which are performed habitually and recurrently in rap. These rituals, I explain elsewhere, are more an expression of politics, moments of identification, and desire than they are of language or of mastering the language per se (Ibrahim, 1999). It is a way of saying, 'I am Black too', or 'I too desire and identify with Blackness.'

Here, Black popular culture refers to films, newspapers, magazines and, more importantly, music such as rap, reggae, pop, and rhythm and blues (R\&B). By hip-hop, more skeletally, I am referring to a way of dressing, walking, and talking. Dress refers to the shades and shapes of the latest fly gear: high-top sneakers, bicycle shorts, chunky jewellery, baggy pants, and polka-dotted tops (Rose, 1991, p. 227). Walk usually means moving the fingers simultaneously with the head and the rest of the body while walking. Talk refers to BSE. In patterning these behaviours, African youth enter the realm of becoming Black. In sum, becoming Black is a subject-formation project (i.e. the process and the space within which subjectivity is formed) that is produced in and simultaneously produced by the process of language learning - in this case, learning BESL. More specifically, becoming Black means learning BESL; yet the very process of learning BESL produces the epiphenomenon of becoming Black.

Becoming Black is both a psychic and phenomenological event that takes place when Black immigrants 'realize' how they are perceived and, hence, are treated as 'Blacks,' where the latter oscillates more towards the negative than the positive (West, 2000). Much like the above study by Bailey, African youth find themselves under a hegemonic gaze - a space of psychic formation - where their multiple identities are under erasure. As a continental African, for example, I was not considered Black in Africa; other terms served to patch together my identity, such as tall, Sudanese, and basketball player. However, as a refugee in North America, my perception of self was altered in direct response to the social processes of racism and the historical representation of Blackness whereby the antecedent signifiers became secondary to my Blackness. I then retranslated my being and became Black. ${ }^{9}$ In the case of African youth, becoming Black is phenomenologically performed in and through their dress, walk and talk.

\section{BESL Learning and the Politics of Identity/Identification}

In Canada, the English language is the usual medium of everyday interaction, except in Quebec. If African youth, and anyone residing outside Quebec want to participate in public life, they have to learn English rapidly. Popular culture, 
especially television, as well as friendship and peer pressures are three mechanisms that hasten the speed of learning English (Ibrahim, 1999); however, making friends, and even learning English, are also influenced by the popular imaginary projected through the dominant source of representation: television. All the students I interviewed answered the question : 'Où est-ce que vous avez appris votre anglais?' (Where did you learn your English?) the same way: 'à la télévision' (from TV). This is signified as television presents a particular representation of Black popular culture that seems to interpellate ${ }^{10}$ (Althusser, 1971) African youth identity and identification. Because African youth have few African Canadian/American friends at first, their access to Black cultural identities and Black linguistic practice is through Black popular culture, especially rap music video-clips, television programs, and Black cinema. When I asked Najat (14, F, Djibouti) ${ }^{11}$ about the most recent movies she had seen, she responded:

Najat: I don't know, I saw Waiting to Exhale and I saw what else I saw, I saw Swimmer, and I saw Jumanji; so wicked, all the movies. I went to Waiting to Exhale wid my boyfriend and I was like 'men are rude' [laughs].

Awad: Oh believe me, I know; I know.

Najat: And den he [her boyfriend] was like 'no, women are rude.' I was like we're like fighting you know and joking around. I was like, and de whole time like [laughs], and den when de woman burns the car, I was like 'go girl!' You know and all the women are like 'go girl!' you know? And den de men like khhh. I'm like 'I'm gonna go get me a pop corn' [laughs].' (individual interview, English)

Najat's response points to two very important phenomena. First, it shows the influence of Black English in the use of de, den, dat, and wicked as opposed to, respectively, the, then, that, and really really good (Smitherman, 2000). Second, it shows that youth bring certain subjectivities to the reading of a text. Indeed, it is these social subjectivities, embedded in history, culture, and memory, which influence what they read and how they read it. Najat's reading of Waiting to Exhale, for example, was interpellated by her race and gender identities. She identified with the Black/woman in burning her husband's car and clothes.

In a similar vein, the following is another example (a videotaped moment) demonstrating the impact of Black popular culture on African students' lives and identities. Just before a focus group interview I had with the boys, Electric Circus, a local television music and dance program that plays mostly, if not exclusively, Black music (rap/hip-hop, reggae, soul and R\&B) began. 'Silence!' one boy exclaimed in French. The boys started to listen attentively to the music and to watch the different fashions of the young people on the program. After the show, the boys code-switched between French, English, and Somali as 
they exchanged observations on the best music, the best dance, and the cutest girl. Rap and hip-hop music and the corresponding dress were at the top of their list.

These moments of identification point to the process of identity formation that is, in turn, implicated in the linguistic norm learned and appropriated. A significant aspect to note about identification is that it works over a period of time and at the subconscious level. Omer (18, M, Ethiopia), in the following excerpt, addresses the different ways in which African youths are influenced by their identification with Black representations:

Black Canadian youths are influenced by the Afro-Americans. You watch for hours, you listen to Black music, you watch Black comedy, Mr. T., ${ }^{12}$ the Rap City. There you will see singers who dress in particular ways. You see, so. (individual interview, French)

Similarly, Mukhi (19, M, Djibouti) argued that:

We identify ourselves more with the Blacks of America. But, this is normal; this is genetic. We can't, since we live in Canada, we can't identify ourselves with Whites or country music, you know [laughs]. We are going to identify ourselves, on the contrary, with people of our colour, who have our life style, you know. (group interview, French) Mukhi's identification with Blackness is clearly pronounced, and for him and all the students I spoke to, this identification was a pivotal part of their identity formation that was linked to their inability to relate to dominant groups, the public spaces they occupy, and their cultural capitals and norms.

Alternatively, Black popular culture, especially rap, emerged not only as a site of identification, but also as a space for language learning; however, it is important to note that rap and its features were more recurrent in the boys' narratives than in the girls'. This raises the question of the role gender plays in the identification process. The following excerpts are two of the many occasions on which students performed their investment in Black North America through the re/citation of rap linguistic styles. ${ }^{13}$

Sam: One two, one two, mic check. A'ait [alright], a'ait, a'ait.

Juma: This is the rapper, you know wha 'm meaning? You know wha 'm saying?

Sam: Mic mic mic; mic check. A'ait you wonna test it? Ah, I've the microphone you know; a'ait.

Sam: [laughs] I don't rap man, c'mon give me a break. [laughs] Yo! A'ait a'ait you know, we just about to finish de tape and all dat. Respect to my main man [pointing to me]. So, you know, you know wha 'm mean, 'm just represen'in Q7. One love to Q7 you know wha 'm mean and all my friends back to Q7 ... Stop the tapin boy!

Jamal: Kim Juma, live! Put the lights on. Wardap. [Students talking in Somali] Peace out, wardap, where de book. Jamal 'm outa here. 
Shapir: Yo, this is Shapir. I am trying to say peace to all my Niggaz, all my bitches from a background that everybody in the house. So, yo, chill out and this is how we gonna kick it. Bye and with that pie. All right, peace yo.

Sam: A'ait this is Sam represen'in AQA [. . . ] where it's born, represen'in you know wha 'm mean? I wonna say whassup to all my Niggaz, you know, peace and one love. You know wha 'm mean, Q7 represen'in for ever. Peace! [Rap music]

Jamal: [as a DJ] Crank it man, coming up. [rap music] (group interview, English)

These excerpts are significant for many reasons. First, because they demonstrate the influence of Black Stylized English, particularly the language of rap: 'Respect for my main man,' 'represen'in Q7,' 'kick the free style,' 'peace out, wardap,' ' 'm outa here,' 'I am trying to say peace to all my Niggaz, all my bitches,' 'so, yo chill out and this is how we gonna kick it,' 'I wonna say whassup to all my Niggaz,' 'peace and one love'. Second, when Shapir offers 'peace to all' his 'Niggaz,' all his 'bitches,' he is indeed repossessing the term Nigga (note the spelling) ${ }^{14}$, a common signifier in rap/hip-hop culture. It is common, for example, to call a Black friend Nigga nowadays without its traditional racist connotation, especially among young people; however, Shapir is using the sort of sexist language that exists in rap (Rose, 1991; Ibrahim, 2000a, b, c). Sexist forms have been challenged by female rappers like Eve, Missy Elliot and TLC, and were critiqued by both female and male students. For example, Samira (16, F, Djibouti) expressed her dismay at the sexist language found in some rap lyrics: 'OK, hiphop, yes I know that everyone likes hip-hop. They dress in a certain way, no? The songs go well. But, they are really really, they have expressions like fuck, bitches etc. Sorry, but there is representation' (group interview, French). Hassan (17, M, Djibouti) put it this way, 'Occasionally, rap has an inappropriate language for the life in which we live, a world of violence and all that' (individual interview, French).

In its broader semiological sense, the language of rap was obviously an influential site of identification and language learning for the boys. Depending on their age, the girls, on the other hand, had an ambivalent relationship to rap. Nonetheless, both boys and girls used the same three strategies in learning ESL in general, and BSE in particular, through music: listening, reading and reciting. Jamal, in the above cited extract, for instance, would listen to tunes and lyrics while reading and following the written text. Acting as a DJ, he then repeated not only the performer's words and expressions, but his accent too. The girls also used similar strategies to Jamal's. During a picnic organized by a mixed group of males and females, for example, they listened to music while following the written text and reciting it (complete with accents) along with the singer. The girls' choice of 
music (e.g. Whitney Houston and Toni Braxton) differed in that it was softer than that chosen by the boys, and contained mostly romantic themes.

In their relation to hip-hop and rap, the older females (16 - 18 years old) tended to be more eclectic for the most part. This was evident in how they dressed, and in the language with which they engaged and that learned. Their clothing was either elegant middle class, partially hip-hop, or traditional, and their learned language was what Philip (1991) calls plain Canadian English. The younger girls (12-14 years), on the other hand, like the boys, dressed in hip-hop style and performed BSE. Nonetheless, I was able to detect three features of BE in both the older and the younger girls' narratives: the absence of the auxiliary 'be', BE negative concord, and the distributive 'be' (for further details, see Ibrahim, 1999).

\section{'Belonging to What?': Identification, Investment, and Desire}

Whether male or female, youth identification with Blackness is volitional, expressing identity formation processes and acts of desire. As Amani (16, F, Somalia) contends:

We have to wonder why we try to really follow the model of the Americans who are Black? Because when you search for yourself, search for identification, you search for someone who reflects you, with whom you have something in common [italics added]. (group interview, French) In my conversation with Mukhi, he expressed similar ideas on the impact of rap (as just one of many forms Black popular culture takes) on his life and others' lives around him:

Awad: But do you listen to rap for example? I noticed that there are a number of students who listen to rap, eh? Is ...

Sam: It is not just us who listen to rap, everybody listens to rap. It is new.

Awad: But do you think that that influences how you speak, how ...

Mukhi: How we dress, how we speak, how we behave [italics added]. (group interview, English)

The linguistic patterns and dress codes that Mukhi is addressing are, on the one hand, accessed and learned by African youth through Black popular culture and, on the other, as I already noted, do not require mastery or fluency. Indeed, they are performative acts of desire and identification. Agreeing with both Mukhi and Amani, Hassan argues:

Hassan: Yes yes, African students are influenced by rap and hip-hop because they want to, yes, they are influenced probably a bit more because it is the desire to belong maybe.

Awad: Belong to what?

Hassan: To a group, belong to a society, to have a model/fashion [he used the term un modèle]; you know, the desire to mark oneself, the 
desire to make, how do I say it? To be part of a rap society, you see. It is like getting into rock and roll or heavy metal. (individual interview, French)

Hence, one may conclude: one invests where one sees oneself mirrored (Ibrahim, 1999: 365). In this sense, an investment is as much linguistic as it is cultural. Hassan indicated in another context that it would be awkward to see Blackness allied with rock and roll or heavy metal, as these are socially constructed as White music. On the other hand, he argued convincingly that African youths would have every reason to invest in basketball - constructed as a Black sport - but not hockey, for example.

\section{The Return of the Repressed: Race-in-Language}

' $[\mathrm{R}]$ ace works like a language . . . That is, there is always, or variously always, a certain sliding of meaning; always a margin not yet encapsulated in language and meaning; always something about race left unsaid; always someone, a constitutive outside, whose very existence the identity of race depends on, and it is absolutely distinct to return from its expel and abject position outside the signifying field, to trouble the dreams of those who are comfortable inside (Hall, 1996). ${ }^{, 15}$

This paper is interested in what Hall (1996) described as the 'sliding of meaning' or the 'left unsaid' about race - or better, racialization - and how it relates to SLA and ESL. Throughout, I have contended that race is left unsaid in the field of second language research: either completely obfuscated or couched under 'ethnicity' (Hall, 1996). In the case of Blackness, and given 'its expel and abject position' and history in North America (and the Western world in general) (Hall 1996), I demonstrated that race was salient - if not absolutely pivotal - in the process of second language learning. Reviewing the literature and exploring my own research, I walked along the roads taken by these African youths in their journey of becoming Black, and gained sight of the outcomes of their journey. Rap and hip-hop were identified as influential sites of identification in these African students' processes of becoming Black, which in turn affected what and how they learned. I have argued that the desire on the part of African youth, particularly the boys, to invest in basketball is analogously no different from their desire to learn BESL; hence, learning is neither aimless nor neutral, nor is it without the politics of identity. As I have shown, a second language learner can have a marginalized linguistic norm as a target, depending on who is learning what, why and how. I have also discussed how these youth are becoming Blacks, which is a subject formation project produced by and producing the very process of BESL. To become Black is to become an ethnographer who translates and looks around in an effort to understand what it means to be Black in Canada, for example. 
In the course of this translation, it is important to note that the White gaze is clearly invisible, and so are the technologies of power and domination (Foucault, 1984). The invisible, however, is very real and, as I have shown, these technologies permeate the fabric of our psyche, our identity, and our ways of being and learning (see also Auerbach, 1995). They are the macro mechanisms of power - including race, gender, sexuality, ability and social class - and we can no longer afford to either disregard them or keep them outside our second language classrooms (Toohey, 2000). They constitute the axes of our identities - the identities we bring to the classroom, which, in the language of antiracism education (Dei, 1996), is the centre of teaching and learning. We need, therefore, to link macro mechanisms of power with micro identity formation processes. That is we need to link the cultural and the political with the linguistic. Especially in the field of applied linguistics, Pennycook has lamented, 'there seems to be a loud absence [of] such connections' (1998, p.19). Yet, as teachers and students, we are part of complex social, economic, and political relations that govern what we teach and learn, and how.

To conclude, I have attempted to show the impact of these complex relations, especially race, on our social identities in this paper. These relations form and transform our subject-or-selfhood, which, in turn, influences our language learning processes and the linguistic norm we move in and eventually learn. In the case of race, we need to re-establish and reposition these racialized subjectivities in language learning mechanisms and technologies, and link the cultural, the social, the political and the stylistic with the linguistic. I hope I have done precisely that. Central to this repositioning, however, are notions of identification, desire and investment. We are yet to desire 'the true word' to be spoken, Paulo Freire argued, only then can we desire 'the world' differently (1993).

\section{Notes:}

1. See Britzman's (2006) definition and use of "imaginary".

2. According to Silverman (2000: 76), suture is "that moment when the subject inserts itself into the symbolic register in the guise of a signifier, and in so doing gains meaning at the expense of being.' That is, suture refers to when something stands-in or takes-the-place-of something or someone, such as my name standing-in for me even in my absence.

3 . These are extremely significant features of immigrants' identity formation processes (see Ibrahim, 2001b).

4. It is common knowledge that there are more genes shared between than among the races (Back and Solomos, 2000).

5. Alchemy for me brings the metaphor of a laboratory and different chemical elements that give certain reactions and transmutations when put together. In the case of race, the social 
context is the laboratory, and the chemical elements are an expression of social struggle and competing definitions of race, defined in accordance with how individuals signify it.

6. For Simon and Dippo (1986: 195), 'critical ethnographic research' is a set of activities situated within a project that seeks and works its way towards social transformation. This project is political as well as pedagogical, and who the researcher is and what his or her racial, gender, and class embodiments are necessarily govern the research questions and findings. The project, then, according to Simon and Dippo, is 'an activity determined both by real and present conditions, and certain conditions still to come which it is trying to bring into being' (p. 196). The assumption underpinning my project was based on the assertion that Canadian society is 'inequitably structured and dominated by a hegemonic culture that suppresses a consideration and understanding of why things are the way they are and what must be done for

7. All names are pseudonyms.

8. This means staying somewhere to familiarize oneself with the place, its people, and their ways of 'being' in that space. In schools, these are informal sites (e.g. hallways, school yards, school steps, the cafeteria and the gymnasium) where people feel comfortable enough to speak their minds.

9. Fanon (1967) sums this idea up brilliantly in his description of himself as a Black 'Antillais' coming to the metropolitan centre of Paris: 'I am given no chance, I am overdetermined from without. I am the slave not of the 'idea' that others have of me but of my own appearance [my italics]. . . . When people like me, they tell me it is in spite of my color. When they dislike me, they point out that it is not because of my color. Either way, I am locked into the infernal circle' (p. 116).

10. Interpellation refers to the subconscious ways in which individuals identify with particular discursive spaces and representations as a result of their genealogical history and memory, and the way this identification subsequently participates in the social formation of the Subject (identity) (Althusser, 1971).

11. Each participant's name is followed by his/her age, gender ( $F=$ female, $M=M a l e)$, and country of origin; and the type of interview (individual or group). The language in which the interview was conducted follows each extract. The following transcription conventions are used:

underlined text English spoken within French speech or French spoken within English speech

[ ] Explanation or description of speaker's actions

[...] Text omitted

12. Mr. T. is an M.C. of a local Canadian rap music TV program called Rap City that airs mostly American rap lyrics.

13. The participants cited in the extracts are Sam (19, M, Djibouti), Juma (19, M, Senegal), Jamal (18, M, Djibouti), and Shapir (17, M, Somalia).

14. To disrupt the racist connotation invoked by the term, Nigga with an 'a' is used for affinity whereas with 'er' for racist purposes (see Smitherman, 2000).

15. My transcript of a seminal lecture by Stuart Hall (1996); see also Hall (1997).

Education canadienne et internationale Vol. 37 nº 2 - décembre 200873 


\section{References:}

Althusser, L. (1971). Lenin and philosophy. London: New Left Books.

Amin, N. (2006). Language, race and the politics of anti-racism. In Amin, N. and Dei, G. (eds) The poetics of anti-racism (pp. 149-158). Halifax: Fernowoord.

Amin, N. (1997). Race and the identity of nonnative ESL teachers. TESOL Quarterly 31, 580-583.

Auerbach, E. (1995). The politics of ESL classrooms: Issues of power in pedagogical choices. In J. Tollefson (ed.) Power and inequality in language education (pp. 933). Cambridge: Cambridge University Press.

Back, L. and Solomos, J. (Eds.) (2000). Theories of race and racism: A reader. London and New York: Routledge.

Bailey, B. (2000). Language and negotiation of ethnic/racial identity among Dominican Americans. Language in Society 29(4), 555-582.

Bakhtin, M. (1990). The dialogic imagination: Four essays. Austin: University of Texas Press.

Barthes, R. (1983). Elements of semiology. New York: Hill and Wang.

Bourdieu, P. (1991). Language and symbolic power. Cambridge, Ma: Harvard University Press.

Britzman, D. (2006). Novel education: Psychoanalysis studies of learning and not learning. New York: Peter Lang.

Butler, J. (1999). Gender trouble: Feminism and the subversion of identity. New York: Routledge.

Cox, O. (2000). Race: A study in social dynamics. New York: Monthly Review Press.

Cummins, J. (2000). Language, power, and pedagogy: Bilingual children in the crossfire. Clevedon: Multilingual Matters.

Dei, G.J.S. (1996). Anti-racism education: Theory and practice. Halifax: Fernwood Publishing.

du Gay, P., Evans, J. and Redman, P. (Eds.) (2000). Identity: A reader. London: Sage Publication \& The Open University.

Eckert, P. and McConnell-Ginet, S. (1999). New generalizations and explanations in language and gender research. Language in Society 28(2), 185-201.

Essed, P. and Goldberg, D. (2002). Race critical theories. Malden, MA: Blackwell Publishers.

Fanon, F. (1967). Black skin white mask. New York: Grove Weidenfeld.

Foucault, M. (1984). The Foucault reader. Harmondsworth, England: Penguin.

Freire, P. (1993). Pedagogy of the oppressed. New York: Coninuum.

Gilroy, P. (2000). Against race: Imagining political culture beyond the color Line. Cambridge, MA: Belknap Press.

Goldstein, T. (1997). Two languages at work: Bilingual life on the production floor. New York: Mouton de Gruyter.

Gumperz, J. (1982). Language and social identity. Cambridge, England: Cambridge University Press.

Hall, S. (1990). Cultural identity and diaspora. In J. Rutherford (ed.) Identity, community, culture, Difference (pp. 222-237). London: Lawrence \& Wishart.

Hall, S. (1991). Ethnicity: Identity and difference. Radical America 13(4), 9-20.

Hall, S. (1996). Race: The floating signifier. [Video-recording]. Northampton, MA: Media Education Foundation. 
Hall, S. (Ed.) (1997). Representation: Cultural representations and signifying practices. London: Sage Publications.

Hall, S. (2000). Old and new identities, old and new ethnicities. In L. Back and J. Solomos (eds) Theories of race and racism: A reader (pp. 144-153). London and New York: Routledge.

Hall, J.K. and Eggington, W.G. (2000). The sociopolitics of English language teaching. Clevedon, England: Multilingual Matters.

Heller, M. (with the collaboration of M. Campbell, P. Dalley and D. Patrick). (1999). Linguistic minorities and modernity: A sociolinguistic ethnography. London: Longman.

hooks, b. (1992). Black looks. Boston, MA: South End Press.

Ibrahim, A. (1998). 'Hey, whassup homeboy?' Becoming black: race, language, culture, and the politics of identity. African students in a Franco-Ontarian high school. Unpublished doctoral dissertation, University of Toronto, Ontario

Ibrahim, A. (1999). Becoming black: Rap and hip-hop, race, gender, identity, and the politics of ESL learning. TESOL Quarterly 33(3), 349-369.

Ibrahim, A. (2000a). 'Hey, ain’t I Black too?' The politics of becoming black. In R. Walcott (ed.) Rude: Contemporary Black Canadian cultural criticism (pp. 109136). Toronto: Insomniac Press.

Ibrahim, A. (2000b). Trans-re-framing identity: Race, language, culture, and the politics of translation. Trans/forms 5(2), 8-25.

Ibrahim, A. (2000c). 'Whassup homeboy?' Black/popular culture and the politics of 'Curriculum Studies': Devising an anti-racism perspective. In G.J. Dei and A. Calliste (eds) Power, Knowledge and Anti-racism Education (pp. 57-72). Halifax, NS: Fernwood Publishing.

Ibrahim, A. (2001). Race-in-the-gap: Émigrés, identity, identification, and the politics of ESL learning. Contact 27 (2), 67-80.

Ibrahim, A. (2003). Black-in-English: Towards a symbolic politics of identification. In G. Smitherman, S. Makoni and A. Ball (eds) Black linguistics: Language, society and politics in Africa and the Americas (pp. 225-232). London: Routledge.

Ibrahim, A. (2008). The new flâneur: Subaltern cultural studies, African youth in Canada, and the semiology of in-betweenness. Cultural Studies 22(2), 234-253.

Kubota, R., \& Lin, A. (Eds.) (2006). Special Issue: Race and TESOL: Introduction to concepts and theories. TESOL Quarterly 40(3).

Morgan, B. (1997). Identity and intonation: Linking dynamic process in an ESL classroom. TESOL Quarterly 31, 431-450.

Morgan, B. (1998). The ESL Classroom: Teaching, Critical Practice, and Community Development. Toronto, ON: University of Toronto Press.

Nelson, C. (1999). Sexual identities in ESL: Queer theory and classroom inquiry. TESOL Quarterly 33 (3), 371-391.

Norton, B. (1997). Special Issue: Language and identity. TESOL Quarterly 31 (3).

Norton, B. (2000). Identity and language learning: Gender, ethnicity and educational change. London: Longman.

Norton, B \& Toohey, K. (eds) (2004). Critical pedagogies and language learning. Cambridge: Cambridge University Press.

Omi, M. and Winant, H. (1998). Racial formations. In P. Rothenberg (ed.) Race, class, and gender in the United States (pp. 13-22). New York: St. Martin's Press. 
Pennycook, A. (1998). English and the discourses of colonialism. London \& New York: Routledge.

Pennycook, A. (Ed.) (1999). Special Issue: Critical approaches to TESOL. TESOL Quarterly 33(3).

Pennycook, A. (2000). The social politics and the cultural politics of language classrooms. In J.K. Hall and W.G. Eggington (eds) The sociopolitics of English language teaching (pp. 89-103). Clevedon, England: Multilingual Matters.

Pennycook, A. (2004). Critical applied linguistics. In A. Davies \& C. Elder (eds) Handbook of applied linguistics (pp. 784-807). Oxford: Blackwell.

Philip, M.N. (1991). Harriet's Daughter. Toronto: The Women's Press.

Rajchman, J. (1995). The identity in question. New York \& London: Routledge.

Rampton, B. (2006). Language in late modernity: Interaction in an urban school.

Cambridge: Cambridge University.

Rampton, B. (1995). Crossing: Language and ethnicity among adolescents. London \& New York: Longman.

Rose, T. (1991). 'Fear of a Black Planet': Rap music and black cultural politics in the 1990s. Journal of Negro Education 60 (3), 276-290.

San Juan, Jr. E. (2002). Racism and cultural studies: Critiques of multiculturalist ideology and the politics of difference. Durham, NC: Duke University Press.

Silverman, K. (2000). Suture: The cinematic model. In P. du Gay, J. Evans and P. Redman (eds) Identity: A reader (pp. 76-86). London: Sage Publications \& The Open University.

Simon, R.I. and Dippo, D. (1986). On critical ethnographic work. Anthropology \& Education Quarterly 17, 195-202.

Smitherman, G. (2000). Black talk: Words and phrases from the hood to the amen corner. Boston, MA: Houghton Mifflin.

Talburt, S. and Stewart, M. (1999). What's the subject of study abroad? Race, gender, and 'Living culture.' The Modern Language Journal 83 (2), 163-175.

Toohey, K. (2000). Learning English at school: Identity, social relations and classroom practice. Clevedon, England: Multilingual Matters Ltd.

West, C. (2000). Race matters. Boston, MA: Beacon.

Wong, S. (2000). Transforming the politics of schooling in the U.S.: A model for successful academic achievement for language minority students. In J.K. Hall and W.G. Eggington (eds) The sociopolitics of English language teaching (pp. 117139). Clevedon, England: Multilingual Matters.

Woodward, K. (1997). Identity and difference. London: Sage Publication \& The Open University.

Yon, D. (2000). Elusive culture: Schooling, race, and identity in global times. New York: State University of New York Press.

Awad Ibrahim is an Associate Professor of Curriculum Theory at the Faculty of Education, University of Ottawa, Canada. He is interested in Hip-Hop studies Black pop culture; racially and linguistically mediated identities; minority adolescents; anti-racism; applied linguistics; semiotics; critical curriculum theory. He is the co-editor (with Samy Alim and Alastair Pennycook) of Global linguistic flows: Hip-Hop cultures, youth identities and the politics of language (Routledge, 2008). He can be reached at<aibrahim@uottawa.ca> . 